\title{
DIE RELIGIEUSE GRONDSLAG VAN ONS OMGEWINGSKRISIS
}

\section{INLEIDING}

Die mensdom is besig om sy habitat op so 'n wyse te misbruik en te besoedel dat sy toekoms op hierdie planeet duister is. In die woorde van White ". . . surely no creature other than man has ever managed to foul its nest in such short order" (1971 p 29). Hierdie stelling is nie oordrewe nie soos blyk uit die vloedgolf van literatuur wat tans verskyn oor hierdie kwessie. Miskien die sprekendste titel onder hierdie bronne wat onlangs verskyn het, is dié onder redaksie van Anderson: "OMEGA: Murder of the Ecosystem and Suicide of Man."

In die lig van die omvattende literatuur wat tans beskikbaar raak, is dit nie nodig om diep hierop in te gaan nie. Enkele voorbeelde is nietemin van pas om die erns van die saak onder die aandag te bring.

Tussen 6 en 10 miljoen ton olie en petroleumprodukte word jaarliks in die see gestort $d \mathrm{~m} v$ riviere. Daarby moet nog gevoeg word die besmetting deur reuse hoeveelhede ander industriële afvalstowwe, slik, chemiese ontsmettingstowwe, bemestingstowwe, insekdoders, ens. Die Rhyn alleen voer miljoene ton chemiese afvalmateriaal jaarliks na die Noordsee. Hierdie afvalstowwe is vinnig besig om die vernaamste visvelde van die kontinentale banke se ekologiese balans te versteur. Dit het Jacques Cousteau genoop om te voorspel dat die oseane binne die bestek van 50 jaar dood sal wees - dié oseane waarop die mens sy hoop gevestig het om binne die volgende 50 jaar 'n verdubbeling in mensegetalle te help voed. Thor Heyerdahl in sy trans-atlantiese vaart per vlot het 'n ononderbroke $2250 \mathrm{~km}$ lange besoedelde seeoppervlakte teengekom. "... his crew had difficulty plucking up the courage to dip their toothbrushes in the water" (Clarke 1974 p 53). Clarke meld ook dat in 'n soektog na 'n gesinkte duikboot daar so baie oliekolle in die Atlantiese oseaan was, dat dit sinneloos was om dit as moontlike ligging van die gesinkte boot te gebruik.

In Suid-Afrika is die mees besoedelde riviergedeelte suid van die Sahara, dié vanwaar een derde van die land se bevolking hul drinkwater kry - die Vaalrivier Barrage. Dié water is só besoedel dat dit reeds vir baie industriële doeleindes onbruikbaar is. 
Dr Kai Curry-Lindahl het bereken dat wind en watererosie oor die wêreld die afgelope eeu meer as $2000 \mathrm{mil}-$ joen ha grond vernietig het. Dit is gelykstaande aan 'n kwart van die aarde se landbougrond (Clarke $1974 \mathrm{p} \mathrm{67).}$ In 1938 het Jacks en Whyte in hul boek "Rape of the Earth" beweer dat nêrens in die wêreld 'n gebied voorkom waar gronderosie so duidelik besig is om 'n nasionale katastrofe te veroorsaak as juis in Suid-Afrika nie. Indien die slik wat jaarliks deur die Tugela vervoer word in drie-ton vragmotors gelaai word, sal dit 'n tou een en 'n driekwart keer om die aarde vorm (Duvenhage, $s$ j p 4). Oorbeweiding het volgens Acocks Suid-Afrika se veld se drakrag in 1966 reeds met $25 \%$ van sy oorspronklike verminder. Erts foto's in 1973 geneem, het getoon dat die Karoo die afgelope 20 jaar $70 \mathrm{~km}$ graslande verplaas het. Dit is een van die oorsake waarom 400 miljoen ton grond jaarliks van Suid-Afrika weggespoel word - genoeg om 'n ploegbare bo-grond vir 10 plase van 1000 ha elk te bied. Geen wonder nie dat Dr Hugh Hammond Bennett die "vader van moderne grondbewaring" van Amerika, nadat hy Suid-Afrika in 1944 besoek het, as afskeidsboodskap gesê het: "Suid-Afrika, ek kry jou jammer." (Robertson 1968, p 37).

Die literatuur oor hierdie onderwerp wemel van nog baie voorbeelde - ook ten opsigte van lugbesoedeling, rondstrooi van rommel, geraas en dies meer.

Waarin moet die oorsaak van hierdie toedrag van sake gesoek word? Omdat die probleem 'n historiese oorsprong het, moet die geskiedkundige ontwikkeling daarvan nagegaan word in 'n soeke na 'n oplossing.

\section{OORSPRONG VAN DIE OMGEWINGSKRISIS}

\section{(i) PRIMITIEWE GEMEENSKAPPE}

Dit word aanvaar deur baie skrywers oor hierdie onderwerp dat die primitiewe jagter en versamelaar geen bedreiging ingehou het vir sy natuurlike omgewing nie. Hy het, net soos die plante en diere, deel van die ekosisteem uitgemaak en moes in volkome harmonie met die ekologiese beginsels leef ten einde te kan bly voortbestaan. Omdat die mens só afhanklik was van die natuur, het sy religie dan ook 'n sterk element van animisme gehad. "In antiquity every tree, every spring, every hill had its guardian spirit ... Before one cut a tree, 
mined a mountain, or dammed a brook, it was important to placate the spirit ..." (White, 1971 p 32). Perpillou (1966, p 39) beskryf hoe dat die Ainus van Hokaido, wat hul lewensbestaan maak uit die jag van bere, deur 'n boetedoeningseremonie moet gaan na elke jagtog. Die primitiewe mens het dus in die ware sin van die woord 'n "heilige ontsag" vir die natuur gehad omdat hy die werking daarvan nie kon verstaan nie, op deterministiese wyse geheel-en-al afhanklik was daarvan en magteloos gestaan het daarteenoor.

Daarby was sy getalle klein en sy eise aan die omgewing proporsioneel gering.

\section{(ii) TEGNOLOGIESE ONTWIKKELING}

Met die ontwikkeling van landbou gedurende die Neolitiese periode (10 000 tot $6000 \mathrm{v} \mathrm{C}$ ) het die prentjie begin verander. As gevolg van die ontwikkeling van werktuie kon die mens in goeie jare mér produseer as wat nodig was vir 'n blote bestaan. Dit het aan hom 'n gevoel van sekuriteit en selfstandigheid gegee. Hy was nie meer geheel-en-al afhanklik van die goeie guns van 'n godheid/geesteswêreld om 'n bestaan te kan maak nie. Dit het hom meer onverskillig ingestel teenoor die natuur as sy animisties-georiënteerde voorouers. Daarby het suiwer ekonomiese beginsels sy boerdery begin oorheers bó die ekologiese beginsels. Wetenskap en tegnologie het dit vir hom moontlik gemaak om steeds meer uit die natuur te haal. Dit het hy dan ook gedoen omdat sy sug na materiële gewin groter was as sy ontsag vir die natuur.

"By the seventeenth century in European philosophy God was outside the system as its mere clockmaker. To the early American, nature was God's provision for man's exploitation ... The con temporary Western world, now immitated by the Orient, tends to regard the relation of man to nature as a relation of man to physical matter in which application of physical science to man's material comfort is man's paramount assignment on earth." (Spoehr, 1956, p 99).

Voortgesette tegnologiese ontwikkeling het die eksploitasie van die natuur moontlik gemaak op 'n skaal wat nie voorsien kon word nie. Hierdie feit is op dramatiese wyse in die V S A beklemtoon deur die gebeure wat gevolg het 
op die Oklahoma-grondstormloop van 1889. Gedurende die Eerste Wêreldoorlog is $163000 \mathrm{~km}^{2}$ van dié groot grasvlakte - waar, in sy natuurlike staat, buffeltroppe op die grasvlaktes gewei het - onder die ploeg gebring en beplant met graan totdat die groot transkontinentale stofstorms (wat tot $\mathbf{3 0 0}$ miljoen ton grond per slag vervoer het) vanuit hierdie prêries oor Washington begin uitsif het.

\section{(iii) OMGEWINGSPERSEPSIE}

Die oorsprong van die ekologiese krisis lê dus tot 'n groot mate in die tegnologiese ontwikkeling van die mens, maar per slot van sake is die mens in beheer van sy tegnologiese uitvindsels sodat ' $n$ wanbenutting van hierdie middele vra om 'n herwaardering van die mens se siening van sy omgewing. Die mens se siening van sy omgewing bepaal tot 'n groot mate hoe hy sy omgewing sal benut. "... culturally determined psychology of the individual determines his feeling towards his environment, and his perception of the nature of his environment determines his response ... To understand man's use of the land, his effect on the land, ... we must then focus on the cultural processes." (Carter, 1968, p 538) Dit is dus nie verbasend dat baie navorsers al die uiteenlopende invloede van verskillende kulture op die fisiese omgewing beskryf het nie. 'n Voorbeeld van die sterk invloed van die mens se persepsie van die natuur op sy dade vind ons uit die middeleeue. Die opkoms van die kerk ten koste van die mag van die staatsgesag in Wes Europa het daartoe gelei dat die religieuse denke 'n baie groot rol begin speel het in mense se optrede. "Thus ... religion became the most dinamic formative influence, undeniably spawning a characteristic world view, or environmental perception among the people." (Rorabacher, 1973, p 35). Die religieuse denke van dié tyd het veral drie temas gepropageer $t \mathrm{w}$ dat

1. die aarde deur God geskep is as woonplek vir die mens:

2. die mens daargestel is om die skepping van God te voltooi; en

3. daar 'n sterk verwantskap bestaan tussen die mens, God en die aarde.

"The Church tought that a Christian farmer entered into a partnership with God. As God had given the farmer a 
mind and the ability to change the landscape, surely this meant that man had been intended to finish the creation by changing the landscape - making the earth a better place in which to live." (Rorabacher, 1973 p 38) Dié benadering het aanleiding gegee tot die grootste landbouuitbreiding wat die wêreld nog gesien het. Dit was die periode waartydens die woude wat destyds byna die hele Wes Europa oordek het, oor groot gebiede uitgekap is.

Dit blyk dus dat die mens se benutting van die natuur tot 'n baie groot mate bepaal word deur sy siening daarvan. Daarteenoor is sy siening van die natuur weer baie beinvloed deur wetenskaplike en tegnologiese ontwikkeling deurdat dit hom minder afhanklik gemaak het van die natuurkragte. Daardeur het hy nie meer die natuur as iets verhewe beskou nie maar as iets wat aan hom onderdanig is.

\section{OPLOSSING VAN ONS OMGEWINGSKRISIS}

Wat staan die mensdom te doen?

(i) DIE ROL VAN WETENSKAP EN TEGNOLOGIE

Die verafgoding van die wetenskap en tegnologie sedert die industriële revolusie van die $18 \mathrm{e}$ en $19 \mathrm{e}$ eeu en die tegnologiese revolusie van die twintigste eeu het daartoe gelei dat 'n groot gedeelte van die mensdom 'n onwrikbare geloof ontwikkel het dat die wetenskap en tegnologie met nuwe uitvindings wel altyd 'n uitkoms sal bewerkstellig waar natuurlike reserwes uitgeput, vernietig of besoedel word. In 1955 byvoorbeeld het die redakteurs van Fortune 'n publikasie getiteld: "The fabulous Future" die lig laat sien. Die hele gees van die werk word weerspieël deur David Sarnoff se stelling: "There is no longer any margin of doubt that whatever the mind of man visualises, the genius of science can turn into functioning fact." (Southwick, 1972, p 81).

Tot 'n sekere mate is hierdie "geloof" geregverdig en moet die wetenskap en tegnologie nie onderskat word nie. Baie van die huidige omgewingsprobleme sal sekerlik daardeur opgelos word soos baie al reeds in die verlede daardeur opgelos is. Londen se grootste omgewingsprobleem aan die begin van die negentiende eeu was die akkumulasie van perdemis in die strate en daar is bereken dat dit teen die einde van die eeu so diep as twee 
meter in die strate sou lê! Nodeloos om te sê dat daar in hierdie berekeninge nie rekening gehou is met o a tegnologiese ontwikkeling op die vlak van vervoermedia nie.

Die vernaamste voorstaanders van hierdie gedagterigting, naamlik dat die wetenskap soewereine beheer oor die natuur uitoefen en dat oplossings vir alle omgewingsprobleme gevind sal word, bou hul teorieë op die werk van Francis Bacon (vroeë sewentiende eeu). "During the twentieth century the Baconian creed has given man the optimism that he can achieve all things. He can control and eliminate disease, produce unlimited food ... (ens.)... and enter a golden age of technology and economic prosperity in which his only remaining problem would be the use of leisure time." (Southwick, 1972, p 80). Hierdie denkrigting voorsien dus geen probleem ten opsigte van voedselproduksie, omgewingsbesoedeling, e d m wat nie deur die mens opgelos sal kan word nie. Die enigste vereiste is dat die wetenskap ongehinderd sy gang moet kan gaan.

(ii) 'N HERORIENTERING IN DIE SIENING VAN DIE MENS TEN OPSIGTE VAN SY OMGEWING

Hierdie optimisme het tot en met die sestiger jare van hierdie eeu die botoon bly voer, maar moes daarna - en veral na 1968 - plek maak vir 'n vloedgolf van pessimisme. Dit is aangevoor deur veral Aldo Leopold (1949) Vogt (1948) en Osborn (1948). Dit het gelei tot 'n aktiewe openbare belangstelling in die gedagte dat die mens alleen onbepaald kan bly voortbestaan indien hy hom weer, soos vroeër, vereenselwig met die ekologiese wette van die natuur en in harmonie daarmee sy bestaan uitwerk.

Om egter in harmonie met die natuur te lewe, behels meer as net ' $n$ reeks wette en tegnologiese aanpassings. Dit vereis ' $\mathrm{n}$ heroriëntering in die denke van die mensdom volgens Kormonde: “... a rethinking of man's place in nature, a rethinking of attitudes about the total environment - in the words of Aldo Leopold, the developement of a new ethic for the land." (1969, p 196)

Die gedagte dat tegnologie alleen nie kan sorg vir 'n oplossing nie, word sterk beklemtoon: trouens tegnologiese "vooruitgang" is juis een van die grootste redes vir 
die omverwerping van die ekologiese balans. "Mankind is engaged in a program of self-defeat ... Technological power is altering environment at an increasing rate, often in ways which are to man's disadvantage... There is no present reason for confidence that man will succeed in bringing about a harmony between his population and environment. It does not seem that technology alone can produce a long-term solution" (Southwick, 1972, p 86). White (asook Clarke, 1974, e a ) is ook van mening dat die oplossing van die ekologiese krisis nie lê in wetenskap en tegnologie nie. "What people do about their ecology depends on what they think about themselves in relation to things around them. Human ecology is deeply conditioned by beliefs about our nature and destiny - that is, by religion" (White, 1971, p 31).

Die oplossing lê dus enersyds wel by die wetenskap en tegnologie, maar andersyds by die persepsie van die omgewing deur die mens en by laasgenoemde speel religie ' $n$ besonder belangrike rol. Die mens se godsdiens en wêreldsiening kan nie losgemaak word van mekaar nie.

\section{(iii) Die Rol van die Christelike Religie}

Die natuur is van die vroegste tye deur die Christendom gesien as die handewerk van God waardeur Hy tot die mens spreek. Die mier spreek tot die luiaard; die reënboog is 'n teken van 'n verbond tussen God en die mens; ens. Teen die 13e eeu het 'n sterk neiging ontstaan om deur middel van navorsing van die natuur, God beter te leer ken. Vir al die vernaamste wetenskaplikes van hierdie tyd, en tot by Leibnitz en Newton, was godsdienstige motivering die dryfveer vir navorsing (White, 1971, p 33). Hieruit wil dit dus blyk dat die moderne Westerse wetenskap "... was cast in a matrix of Christian theology. The dynamism of religious devotion, shaped by the JudeoChristian dogma of cration, gave it impetus" (White, 1971, p 33). Vanweë die noue verband tussen tegnologiese ontwikkeling en wetenskapbeoefening, is e.g. dus ook, so gesien, gefundeer in die Christelike religieuse denke. Hieruit lei White af dat, omdat tegnologie verantwoordelik is vir die wanbenutting en wanbalans in die ekosisteem, dit dus die Christendom is wat daarvoor veran twoordelik is. "No clear set of basic values has been accepted in our society to displace those of Christianity. Hence we shall continue to have a worsening ecological 
crisis until we reject the Christian axiom that nature has no reason for existence save to serve man" ( $p 35)$. Volgens White is hierdie aspek van die Christelike geloof dus die grondslag van ons omgewingskrisis deurdat dit die mens los gemaak het van sy intieme verhouding met die natuur as déél daarvan wat hy dus ten volle moet bewaar en koester.

Hierdeur word hy nou die heerser, die eksploiteerder, vir sy eie gewin. Dit noem hy "The Historical Roots of Our Ecological Crisis". "Christianity is the most anthropocentric religion the world has seen. Christianity ... established a dualism of man and nature ... (p 240).

Die slotsom waartoe White kom, is dus dat "More science and more tectinology are not going to get us out of the present ecological crisis until we find a new religion, or rethink the old one"(p 34).

Toynbee (1972) blameer ook die Christelike godsdiens dat hy panteisme vervang het met die aanbidding van 'n enkele God wat losstaan van die natuur. Voorts ontvang die mensdom volgens Toynbee 'n mandaat van God (volgens Genesis 1:28 "... onderwerp ... en heers ...") om soveel voordeel uit die natuur te haal as moontlik.

Kan ons hierdie argumente aanvaar? Daar moet erken word dat daar' $n$ mate van waarheid in is. Daar is egter ook ernstige leemtes daarin. So byvoorbeeld is daar baie ander godsdienste wat net soveel of selfs meer skade aan die omgewing aangerig het as die Christendom. Die Chinese religieuse denke het by voorbeeld o a baie klem gelê op die eenheid van mens en natuur. Veral Lao-tsu se leerstellings het beklemtoon dat die mens moet aanleer om in harmonie met die natuur te lewe en om homself te sien as 'n onbenullige element in die groot universele orde (De Blij, $1974 \mathrm{p}$ 181). Dit het egter nie verhoed dat die Chinese landskap onderhewig is aan omgewingsmisbruik nie. In die noordelike dele van Sirië waar die Christelike geloof relatief min invloed gehad het, kom die ernstigste graad van erosie bekend, voor.

Dat daar egter 'n element van waarheid in White en Toynbee se stellings is, moet toegegee word. Die Christendom hét die natuur (wat as pand aan hom toevertrou is) misbruik. Dit sou egter onskriftuurlik wees om 
hierdie ekologiese krisis aan die Christelike godsdiens self toe te dig. As God aan die mens sê dat hy oor die skepping moet heers (Gen. 1:28) is die implikasie beslis nie dat dit verniel mag word nie. In Gen 2:15 sê God juis dat die mens die aarde moet bewerk en dit bewaak. Hier het ons inderwaarheid ' $n$ positiewe bevel tot natuurbewaring. Die oorsaak van die omgewingskrisis lê eerder daarin dat die mens, deur die sondeval, sy eerste liefde vanaf God en sy Skepping weggekeer het en op homself gerig het. Só gesien, is die sóndeval die grondoorsaak van die mens se materialisme wat lei tot die maksimum eksploitasie van die natuur. Die sug na maksimum wins, ongeag die nadelige newe-effek daarvan op die medemens of omgewing, is die basis van ons omgewingskrisis - nie die Christelike godsdiens nie!

Daar is egter 'n verdere aspek wat ook ons aandag vereis. Die skeppingsopdrag van God aan die mens behels veel meer as net dat die mens dit nie mag misbruik en dus die vernieling daarvan moet afkeur nie. Hy mag nie passief staan teenoor die beskadiging daarvan nie. Volgens Rowland Moss (ongekwoteerde werk uit Van Wyk, s j p 9) kom die implikasies van die skeppingsopdrag op die volgende neer:-

1. Die mens moet die natuur benut vir sy daaglikse voorsiening.

2. Die mens moet voortdurend poog om 'n beter begrip te verkry van die natuur.

3. Die mens moet die natuur bewaar vir die nageslag se behoeftes.

4. Die mens moet die natuur as skepping van God bewonder en geniet.

5. Die mens moet dankbaarheid betoon teenoor God vir die Skepping van die natuur waardeur aan sy daaglikse behoeftes voorsien word.

"Aangesien die voortdurende voortbestaan van alle lewe van oordeelkundige natuurbenutting afhanklik is, spreek dit vanself dat dit die Christen se plig is om natuurbewaring toe te pas waar dit nodig is" (Van Wyk, $p$ 
10). Dit kan hy beter doen as hy dus meerdere kennis daarvan najaag. Te midde van so 'n ongeskonde natuur sal hy God ook beter kan loof en dank vir die skepping daarvan.

Die Christen se beskouing van die natuur word deur Calvyn soos volg saamgevat:- "... the custody of the garden was given in charge to Adam, to show that we possess the things which God has committed to our hands, on the condition that being content with the frugal and moderate use of them, we should take care of what shall remain. Let him who possesses a field, so partake of its yearly fruits, that he may not suffer the ground to be injured by his negligence; but let him endeavour to hand it down to posterity as he received it, or even better cultivated. Let him so feed on its fruits, that he neither dissipates it by luxury, nor permits to be marred or ruined by neglect. Moreover, that this economy, and this diligence, with respect to those good things which God has given us to enjoy, may flourish among us; let every one regard himself as the steward of God in all things which he posesses. Then he will neither conduct himself dissolutely, nor corrupt by abuse those things which God requires to be preserved." (Ongekwoteerde aanhaling oorgeneem uit Van Wyk, s j p 12).

\section{SAMEVATTING}

Daar is voldoende bewys dat die mensdom wel voor 'n lewensbeslissende omgewingskrisis te staan gekom het. 'n Voortgang op die huidige weg beteken sy eie uitwissing op aarde.

Die resepte vir'n oplossing van die probleem val duidelik in twee kategorieë uiteen:-

1 Meer intensiewe wetenskaplike navorsing om die dilemma waarin die mens homself juis a $g \mathrm{v}$ hierdie wetenskaplike uitbreiding gedompel het, reg te stel.

2. 'n Drastiese opvoedingsprogram vir alle mense. Daar kan nie gewag word totdat die ekologiese balans totaal versteur is en mense wêreldwyd begin hongerly voordat almal se samewerking, uit nood gebore, verkry word nie. 
Soos reeds gesê, is wetenskaplike ontwikkeling nie die finale antwoord nie. 'n Algemene opvoedingsprogram alhoewel noodsaaklik, het ook sy beperkte waarde. Om die mensdom te oorreed om sy winsmotief in te kort $t w v$ sy medemens en die nageslag en sodoende sy eie gerief op te offer, en dit alles net deur 'n algemene opvoedingsprogram, blyk geensins waarskynlik te wees nie. Dit wil nie sê dat die wetenskap nie 'n belangrike rol te speel het in die oplossing van die probleem nie. So ook sal die opvoedingsplan sy vrugte hê - veral onder dié wat humanisties georiënteerd is of 'n sterk gevoel het vir die natuur, maar dit is ydele hoop om te dink dat die uiteindelike finale krisis daardeur afgewend sal kan word. Daar bly uiteindelik net een oplossing oor: die mensdom moet weer die mees grondliggende wet van die Christendom (en van die heelal) $t w$ om God (en sy Skepping) en medemens lief te hê-desnoods ten koste van homself herontdek en dit prakties uitleef. As die "liefde wat die naaste geen kwaad aandoen nie" weer sy regmatige plek sou kon inneem, sou die industrialis nie afvalstow we op onverantwoordelike wyse in ander se drink- en besproeiingswater stort nie; die boer sal nie die opvanggebiede van riviere laat oorbewei $t w v$ ekstra wins en daardeur sy buurman se damme laat toeslik nie; die piekniekmaker sal nie sy leë blikkies rondstrooi omdat sy gerief vir hom meer werd is as die volgende man se verlange na die ongeskonde natuuromgewing nie. In die praktiese lewe beteken die Christelike leerstellings vir'n baie groot deel van die Christendom nie meer veel nie. Die Christendom kan nie ontken dat hy in 'n doodse formalisme verval het nie. Die wonder van die natuur soos in Ps 104 besing word, spreek nie met dieselfde impakt tot die industrialis, boer of streeksontwikkelaar soos die finansiële gewin wat hy daaruit kan haal nie. Daarom is White reg as hy sê: "Since the roots of our trouble are so largely religious, the remedy must also be essentially religious, whether we call it that or not" (p 35).

M L HUGO

PU vir CHO 


\section{BIBLIOGRAFIE}

P K ANDERSON, (Red) (1971), OMEGA: Murder of the Ecosystem and Suicide of Man. Brown Co, Dubuque, Iowa.

G F CARTER, (1968),: Man and the Land. A Cultural Geography (2e uitgawe). Holt, Rinehart \& Winston, N Y.

J CLARKE, (1974), Our Fragile Land. South Africa's Environmental Crisis. MacMillan S A, Johannesburg.

H J DE BLIJ, (1974), Man Shapes the Earth. A Topical Geography. Hamilton Publ Co, Santa Barbara.

A DU PLESSIS, (red) (1974), Die Bewaring van ons Erfenis. Human \& Rosseau, Kaapstad.

A DUVENAGE, ( $\mathrm{j}$ ), Gods hand in die Natuur. Studiestuk nr 4, Instituut vir Bevordering van Calvinisme, $\mathrm{P} \mathrm{U}$ vir $\mathrm{C} \mathrm{H} \mathrm{O}$, Potchefstroom.

J J DUVENA GE, (s j), Natuurbewaring - 'n Noodsaaklikheid. Studiestuk nr 23, I B C, P U vir C H O, Potchefstroom.

C J GLACKEN, (1956), Changing Ideas of the Habitable World. In: W L Thomas, (red), Man's role in changing the Face of the Earth. University of Chicago Press, Chicago.

E J KORMANDY, (1969), Concepts of Ecology. Prentice Hall, New Jersey.

A LEOPOLD, (1949), The Land Ethic. An essay in A Sandy Country Almanac. Oxford University Press, N Y (pp 201 - 226).

I A MATLEY, (1966), The Marxist approach to the geographical environment. Annals of the Assn of American Geographers. Vol $56 \mathrm{pp}$ $97-111$.

F OSBORNE, (1948), Our Plundered Earth. Little Brown, Boston.

A V PERPILLOU, (1966), Human Geography. Longmans, London.

T C ROBERTSON, (1968), Grond is Lewe. Kaapstad.

J A RORABA CHER, (1973), Geo-historical approaches to Environment: The evolution of environmental thought in Western Civilization. Journal of Geography. Vol $72 \mathrm{nr} 4$ (pp 31 - 41).

C H SOUTHWICK, (1972), Ecology and the Quality of our Evironment. Van Nostrand, $N$ Y

A SPOEHR, (1956), Cultural differences in the Interpretation of Natural Resources. In: W L Thomas, (1956), Man's role in changing the Face of the Earth. University of Chicago Press, Chicago.

A TOYNBEE, The Religious Background of the Present Environmental Crisis. Int J Environmental Studies. Vol 3 (pp 141 - 146).

J J P VAN WYK, (s j), Die Probleem van Omgewingsbesoedeling. I B C Studiestuk nr 73. P U vir C H O. Potchefstroom.

W. VOGT, (1948), Road to Survival. William Sloane associates, N Y H L WATTS, (1973), A consideration of Sociological factors involved in community development. Simposium: "Die Mens en sy Omgewing", Universiteit van die Noorde, Sovenga.

M WEBER, (1930), Protestant Ethic and the Spirit of Capitalism. Allen \& Unwin, London.

L WHITE, (1971), The Historical roots of our ecological crisis. In: T R Detwyler, (red) (1971), Man's Impact on Environment. McGraw-Hill, N $\mathbf{Y}$ 